\title{
CHARACTERIZATION AND REUSING OF EXHAUSTED PETROLEUM GAS MOLECULAR SIEVES SORBENT MEDIA TO BE USED IN THE TREATMENT OF INDUSTRIAL WASTEWATER
}

\author{
Hewaihy, M.A. I. ${ }^{(1)}$; Abd El Razek, T. A. M. ${ }^{(1)}$; Hafez, A. I. ${ }^{(2)}$ \\ and Abu Neama, Rania, $F^{(3)}$ \\ 1) Institute of Environmental Studies and Research, Ain Shams University \\ 2) Central chemical Lab. Electricity Transmission Holding co. \\ 3) Environmental specialist, Egyptian Natural Gas Holding co.
}

\begin{abstract}
Exhausted molecular sieves sorbent media (EMSSM) used in the purification of petroleum gases is considered industrial waste causing disposal problem. This work carried out to utilize this waste in the treatment of industrial wastewater.X-Ray analysis revealed that the main constituents of (EMSSM) are like bentonite and most clay. (EMSSM) material was tested in different forms (untreated, chemically treated, thermally treated) for remove these parameters from industrial wastewater (organic matter, oil and grease, turbidity and some metal) which tested as jar test with and without ferric chloride as flocculants ,the chemical and thermal treatment were applied on (EMSSM) in order to increase its adsorption efficiency. Characteristics of these sorbents were investigated by X-ray diffraction, Energy Dispersive X-Ray (EDX), thermogravimetric analysis (TGA). The untreated, chemically treated, thermally treated (EMSSM) were found to remove organic matter from industrial wastewater with removal percentage reached to $(70.47 \%)$, $(78.63 \%)$ and $(86.81 \%)$ respectively. The factors affecting the removal percentage such as time, dose, $\mathrm{pH}$ and temperature were investigating to assess the optimum conditions for turbidity, organic matter and oil and grease removal.
\end{abstract}

Key word: molecular sieve, adsorbent materials, water treatment, clay. 
J. Environ. Sci.

Institute of Environmental Studies and Research - Ain Shams University

\section{INTRODUCTION}

Natural gas is a valuable resource both as a clean source of energy and as a chemical feedstock. Before use, it has to pass several processing steps. These steps are necessary to be able to transport the gas over long distances and for the recovery of valuable components contained in the gas.

Molecular sieve is one of potential stages for natural gas cleaning that could be applicable for removal of mercury, water, others, this sieve depends on zeolite structure, numerous zeolite species that differ in chemical composition, crystal structure and adsorption properties are known (Bekkum and Jacobs, 2001). After several times of operation, molecular sieves were exhausted. The amount of exhausted molecular sieves is approximately high, where total quantities of molecular sieves contaminated is 50 ton / year in natural gas sector in Egypt (personal communication).

Clay minerals, such as bentonite and zeolite, are some of the potential alternatives, as they have large specific surface areas with a net negative charge, which can be electrically compensated for by inorganic and organic cations from water (Konig et al., 2012) compared to poly aluminum chloride. Their sorption capabilities come from their high surface areas and exchange capacities (Babel and Kurniawan, 2003). It is a highly effective natural clay mineral, especially in granular form, used for the purification of wastewater and sludge dewatering.

Clay used in conjunction with alum or ferric chloride, result in improved turbidity and colour removals from wastewater (Mittal and Mehrotra, 1981). 
Kendall (1996) indicated that, the efficiency of clay could be improved with acid activation of some clay such as sodium-bentonite "NaB", calciumbentonite "CaB", beige sepiolite "BeS", and brown sepiolite "BrS". The "thermal activation process" suggested by (Juang et al., 1997) was also applied.

Also acid treatment was used to remove cations from the crystal structure to give clay with improved porosity and higher surface area, which enhance both adsorption capacity, and chemical properties such as ion exchange capacity and catalytic activity (Kendall, 1996).

(Dilek and Bese, 2001), (Stephenson and Duff, 1996), was found, the use of clay as a coagulant aid in water treatment by alum, ferric chloride and lime the turbidity and colour removal efficiency was improved to some extent, especially at combinations with low alum or ferric chloride dose, for the clays tested.

The use of clay mineral has undoubtedly become more popular and widely used as an adsorbent and ion exchange for water and wastewater treatment applications especially for removing heavy metal, organic pollutants, and nutrients (Abdelaal, 2004).

Some zeolites also show adsorption of organics and anions from aqueous solution. Modification of natural or synthetic zeolites can be done by several methods such as acid treatment, ion exchange where the modified zeolites achieving higher adsorption capacity for organics (Wang and Peng, 2009).

This work is dealt with the reuse of untreated, thermally and chemically treated petroleum gas molecular sieves to be used as clay in the treatment of wastewater. 


\section{MATERIALS AND METHODS}

1. (EMSSM) source: The exhausted molecular sieves sorbent agents were collected from Natural gas treatment process unit in Alexandria-Egypt. The typical and powder (EMSSM) photographs are shown in Figure (1):

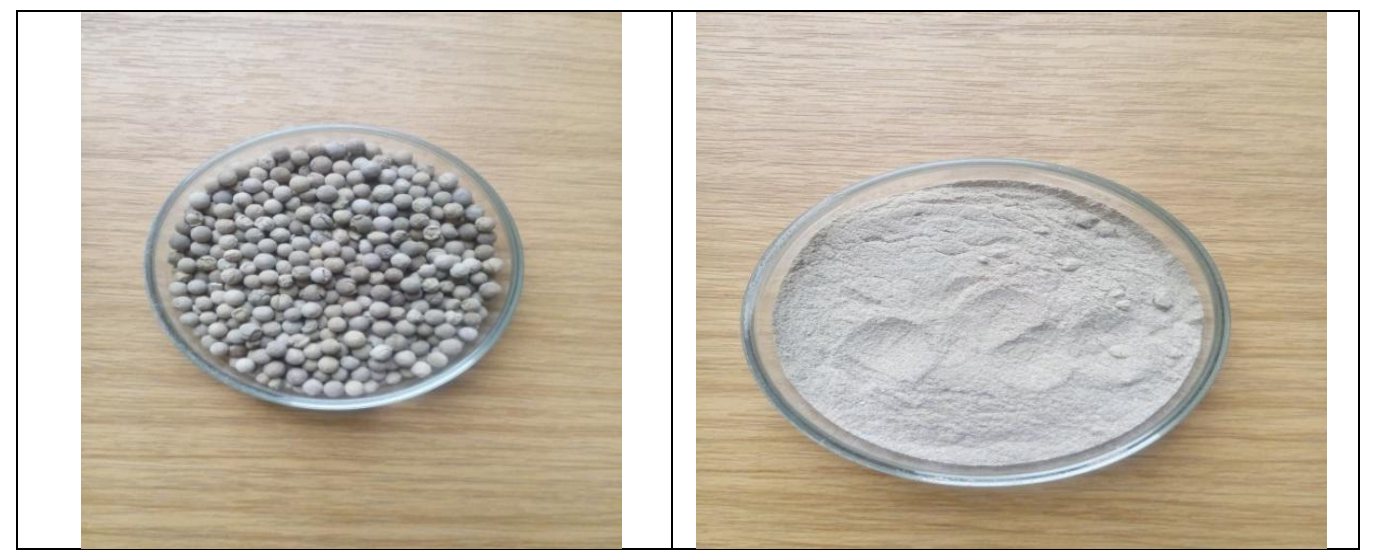

Figure (1): typical and powder (EMSSM)

2. Chemical treatment of (EMSSM): The chemical treatment of (EMSSM) was conducted as follows:

A known weight of powdered used (EMSSM) was contacted with different concentrations of hydrochloric acid [1\% to $5 \%$, then shaked in a thermostatic water bath shaker for 2 hours at room temperature. Finally, variable weights of the tested (EMSSM) were contacted with industrial waste water samples and phases were separated by centrifugation and filtration.

3. Thermal treatment of (EMSSM): The thermal treatment of (EMSSM) was conducted as a known weight of powdered used (EMSSM) was heating in burning oven for 4 hour at 400, 600 and $800^{\circ} \mathrm{C}$, and left to cool in the desiccator until use. 


\section{Analysis:}

\section{1. (EMSSM) analysis:}

- Thermogravimetric Analysis (TGA): Thermogravimetric analyses of the (EMSSM) were performed using thermogravimetric determenator Leco: Mac-500.ST.Joseph, Michigan-USA. This apparatus provides a continuous measurement of sample weight at a range of temperatures between ambient and $700^{\circ} \mathrm{C}$. The samples were heated in an alumina cell to $700{ }^{\circ} \mathrm{C}$ at heating rate of $10^{\circ} \mathrm{C} / \mathrm{min}$ with nitrogen as the circulating gas.

- X-ray analysis of (EMSSM):

The (EMSSM) was analysed using the following devices:

1-X-Ray diffraction (XRD) was measuring by XRD spectrophotometer, X'pert pro-PAN Analytical

2- Energy Dispersive X-ray System, ISIS Link Instrument P/C. Oxford Co.

- Ignition loss was measured by heating of (EMSSM) at $700^{\circ} \mathrm{C}$ until constant weight was obtained.

-Elements in (EMSSM) and aliquot were quantifying using Atomic Absorption Spectrometer, Solaar S-4 S- Series Thermo Electron Corporation UK.

\section{Industrial wastewater analysis:}

- Turbidity was measured in nephelometric turbidity units (NTU) using Helige digital direct reading turbidmiter.

- Water conductivity was measured in microsiemens ( $\mu . s)$ using conductivity meter model 32 Yellow springs instrument Co.Inc.U.S.A.

- Total suspended solids (TSS) was measured by filtering the wastewater samples through a weighed standard glass-fiber filter with $0.2 \mu \mathrm{m}$ 
diameter. The residue on the filter was dried at $110^{\circ} \mathrm{C}$. The increase in the weight of the filter represents the total suspended solid.

- $\mathrm{pH}$ of wastewater was measured by accumet $\mathrm{pH}$ meter model 810 Fisher scientific.

-Solution cations, sodium, potassium, ammonium, magnesium, and calcium were analyzed using a Dionex Ion Chromatograph.

- The organic matter expressed as $\mathrm{KMnO}_{4}$ was determined by consumption of $\mathrm{KMnO}_{4}$ in acidic solution.

- The removal efficiency (\% Removal) was calculated from this formula:

\%Removal $=\left(\mathrm{C}_{\mathrm{o}}-\mathrm{C} / \mathrm{C}_{\mathrm{o}}\right) \times 100$

Where, $\mathrm{C}_{\mathrm{o}}$ and $\mathrm{C}=$ Oil and grease, organic matter, TSS and turbidity contents of wastewater $(\mathrm{mg} / \mathrm{l})$ before and after coagulation treatment, respectively.

- Physical and chemical parameter measurements were carried out according to (APHA, 2012).

3. clarification processes: Jar tester contains six (1 liter) beakers in conjugation with multiple stirrers was used. Each beaker was filled with one liter of raw water and stirred at $100 \mathrm{rpm}$. The different doses of coagulant were added rapidly and stirred for 3 minutes. The stirring rate was then reduced to 50 and $20 \mathrm{rpm}$ for a period of 5 and 10 minutes, respectively to allow complete floc formation, and then stirring was stopped. The relative settling rate, floc size and supernatant clarity were recorded. After a settling period of 15 minutes, $250 \mathrm{ml}$ of supernatant water were siphoned -off for further analysis. 


\section{RESULTS AND DISCUSSION}

\section{Analysis of the untreated exhausted, thermally and chemically treated} molecular sieves sorbent media (EMSSM):

1.1- Chemical analysis: The chemical analysis of the untreated, Chemically treated and thermally treated at $600^{\circ} \mathrm{C}$ of (EMSSM) are listed in Table (1) from which it is clear that the main components of untreated (EMSSM) were $55.59 \% \mathrm{SiO}_{2}, 25.78 \% \mathrm{Al}_{2} \mathrm{O}_{3}, 5.78 \% \mathrm{Fe}_{2} \mathrm{O}_{3}, 1.79 \% \mathrm{TiO}_{2}, 1.03 \% \mathrm{CrO}, 2.59 \%$ $\mathrm{CaO}$. The chemical component of thermally treated of (EMSSM) were $58.60 \% \mathrm{SiO}_{2}, 28.41 \% \mathrm{Al}_{2} \mathrm{O}_{3}, 6.42 \% \mathrm{Fe}_{2} \mathrm{O}_{3}, 1.83 \% \mathrm{TiO}_{2}, 1.13 \% \mathrm{CrO}$ and $3.61 \% \mathrm{CaO}$, Table (1). Also the chemical component of chemically treated of (EMSSM) were $56.30 \% \quad \mathrm{SiO}_{2}, 26.85 \% \mathrm{Al}_{2} \mathrm{O}_{3}, 4.76 \% \mathrm{Fe}_{2} \mathrm{O}_{3}, 0.83 \% \mathrm{TiO}_{2}$, $0.13 \% \mathrm{CrO}$ and $1.7 \% \mathrm{CaO}$, Table (1), where $\mathrm{Al}_{2} \mathrm{O}_{3}$ and $\mathrm{SiO}_{2}$ results were increased in chemically and thermally treated than untreated (EMSSM), while $\mathrm{Fe}_{2} \mathrm{O}_{3}, \mathrm{TiO}_{2}, \mathrm{CrO}, \mathrm{CaO}$ results were decreased in chemically treated due to the action of acid than thermally treated on such metal oxides.

Table (1): Chemical constituents of untreated, chemically and thermally treated (EMSSM)

\begin{tabular}{|c|c|c|c|}
\hline $\begin{array}{c}\text { Chemical } \\
\text { constituent of } \\
(\mathbf{E M S S M})\end{array}$ & $\begin{array}{c}\text { \% untreated } \\
\text { exhausted } \\
\text { (EMSSM) }\end{array}$ & $\begin{array}{c}\text { \% Thermally } \\
\text { treated } \\
\text { (EMSSM)at400 }\end{array}$ & $\begin{array}{c}\text { chemically } \\
\text { Treated } \\
\text { (4\% HCI)(EMSSM) }\end{array}$ \\
\hline \hline $\mathrm{SiO}_{2}$ & 55.59 & 58.60 & 56.30 \\
\hline $\mathrm{Al}_{2} \mathrm{O}_{3}$ & 25.78 & 28.41 & 26.85 \\
\hline $\mathrm{Fe}_{2} \mathrm{O}_{3}$ & 5.78 & 6.42 & 4.76 \\
\hline $\mathrm{TiO}_{2}$ & 1.79 & 1.83 & 0.83 \\
\hline $\mathrm{CaO}$ & 2.59 & 3.61 & 1.7 \\
\hline $\mathrm{CrO}$ & 1.03 & 1.13 & 0.13 \\
\hline $\begin{array}{c}\text { Loss on ignition } \\
\text { at } 800{ }^{\circ} \mathrm{C}\end{array}$ & 7.7 & --- & 5.43 \\
\hline
\end{tabular}


1.2- X-Ray analysis: The X-ray diffraction of the exhausted untreated (EMSSM) is shown in Figure (2). It is clear that the main constituents are quartz, kaolinite $\mathrm{Al}_{2} \mathrm{Si}_{2} \mathrm{O}_{5}(\mathrm{OH})_{4}$ and montnorillonite $\mathrm{AlSi}_{2} \mathrm{O}_{6}(\mathrm{OH})_{2}$ (Betancourt , (2013) ),( Zhao, G, 2010),( Samiey , 2014)

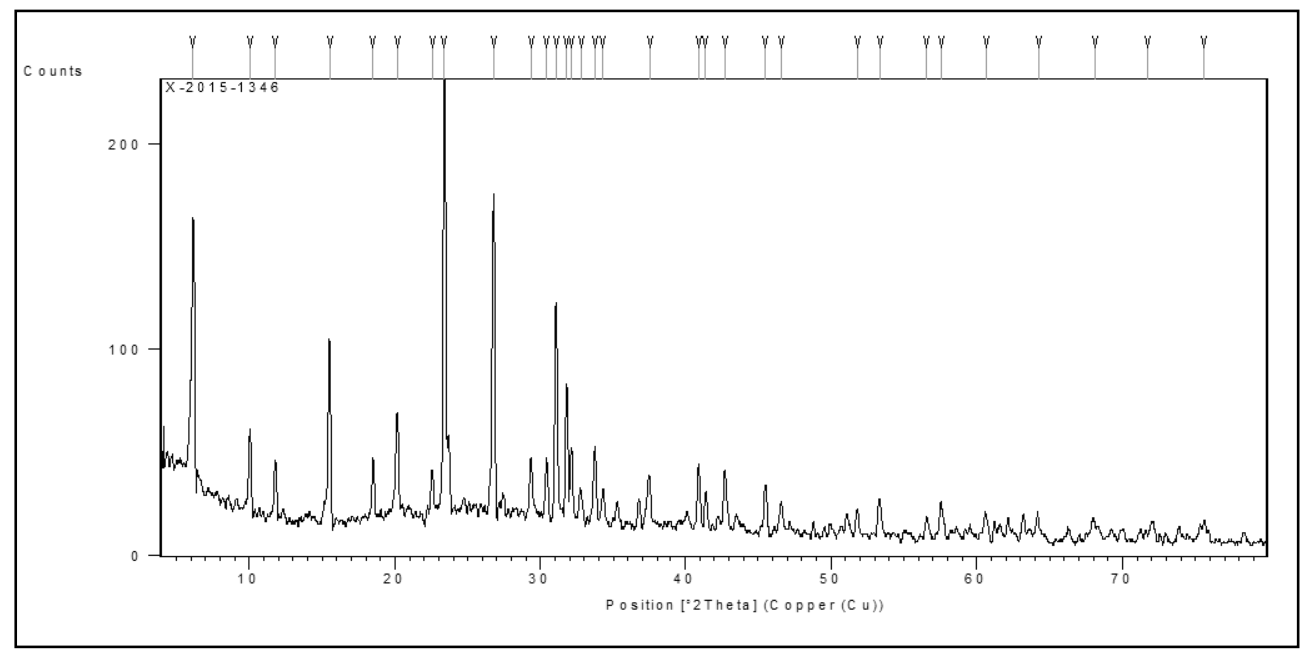

Figure (2): X-ray diffraction of (EMSSM).

The untreated, thermally treated and chemically treated (EMSSM) were analyzed by using; Energy Dispersive X-ray System. Results are shown in Figures $(3,4$, and 5$)$ for the three types of (EMSSM). It is clearly seen that the amount of aluminium and silicon elements represented by the peak of Figures $(3,4)$ is higher compared to other metal element in all types of (EMSSM). While iron and calcium elements represented by the peak of Figure (4) of thermally treated, (EMSSM) is higher compared to Figure $(3,5)$ which represent the untreated and chemical treated (EMSSM). In addition, Figures $(3,5)$ show other elements presented in the different types of (EMSSM) such as $\mathrm{Ti}$ and $\mathrm{Cr}$, which have a small peaks value. 


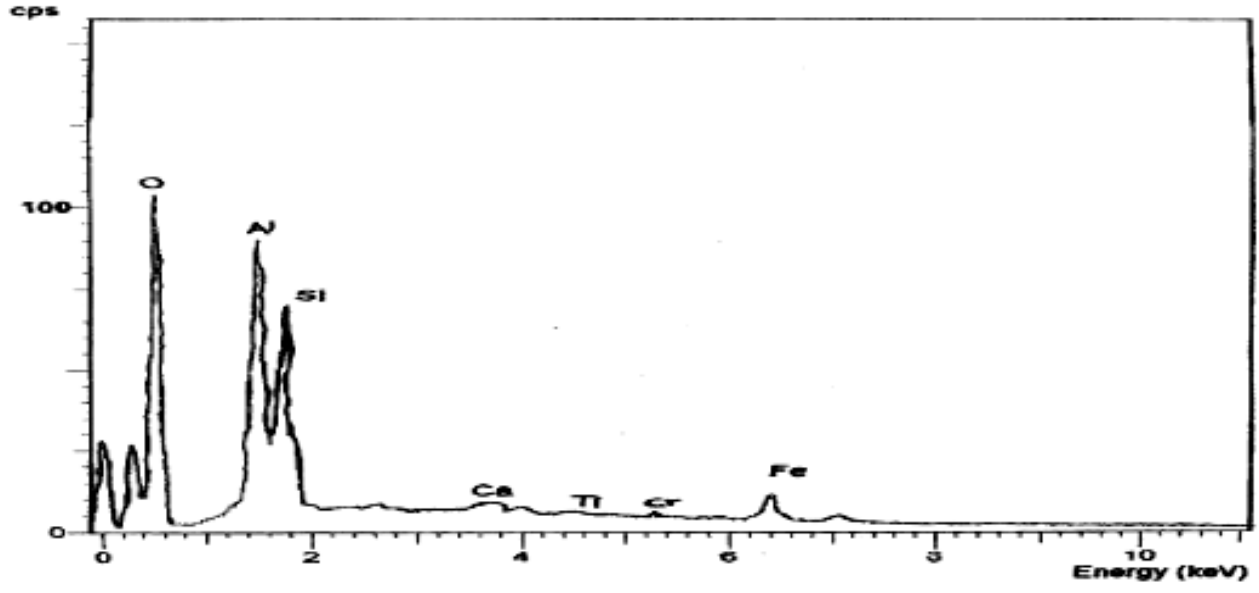

Figure (3): X-ray analysis (EDX) of untreated (EMSSM)

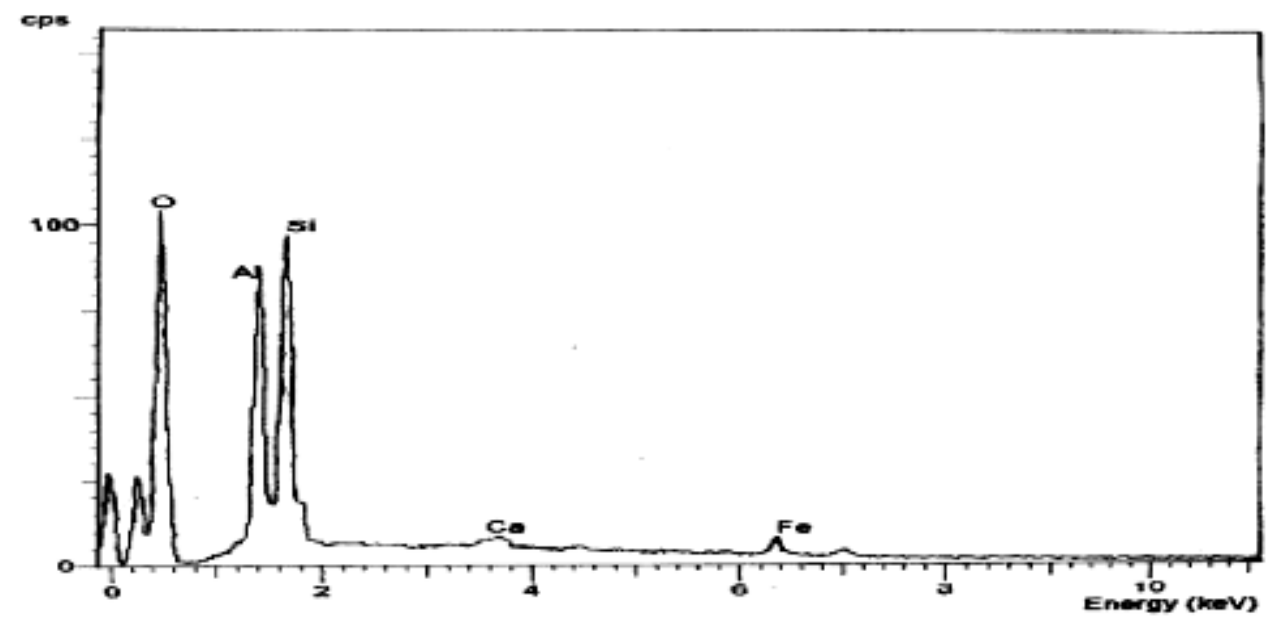

Figure (4): X-ray analysis (EDX) of thermally treated (EMSSM) 


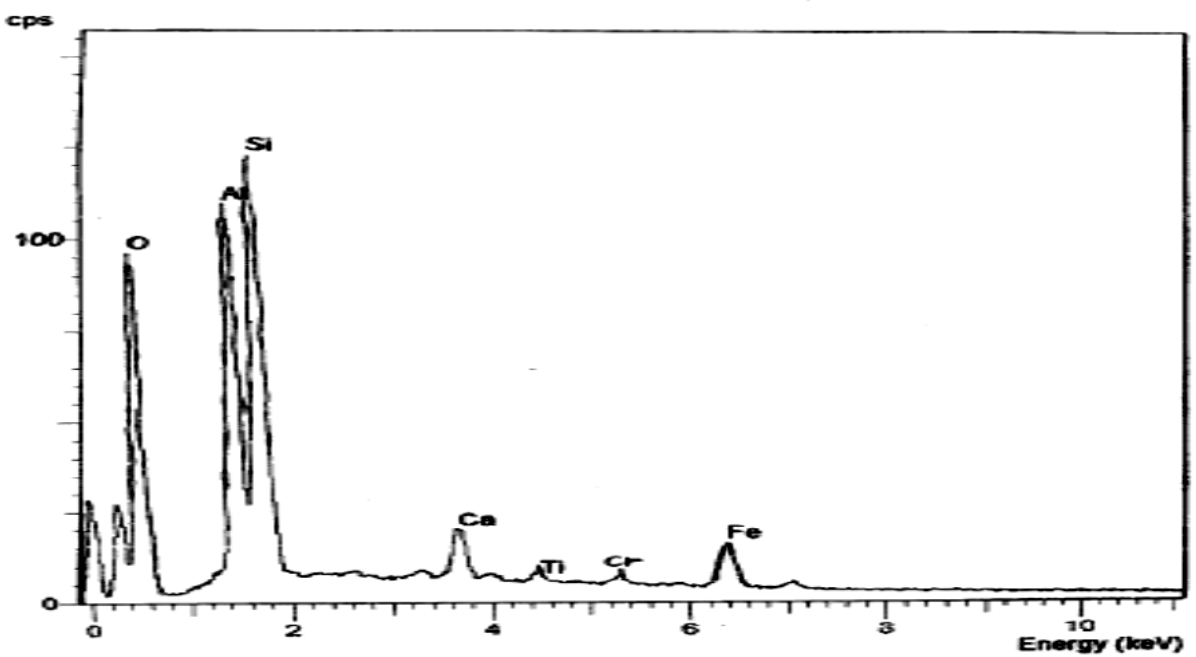

Figure (5): X-ray analysis (EDX) of chemically treated (EMSSM) by $4 \%$ $\mathrm{HCl}$.

1-3. Thermogravimetric analysis: Figure (6) showed the thermogravimetric analysis for the (EMSSM). As it is shown the weight loses at different temperatures are small, where at $100^{\circ} \mathrm{C}$ loss of $3 \%$. This could be recognized due to the moisture content of the sample. The weight loss at 200, 300 and 400 were 5, 6 and 7.4\% respectively. The second stage which related to the main decomposition of the (EMSSM) sample and represented the hydrated hydroxide $\left[\mathrm{Al}_{2}\left(\mathrm{Si}_{2} \mathrm{O}_{5}\right)(\mathrm{OH})_{4}\right],\left[\mathrm{Al}(\mathrm{OH})_{3} \cdot \mathrm{xH}_{2} \mathrm{O}\right]$ and others. After that, the change in weight is very small, where at 500,600 and $700{ }^{0} \mathrm{C}$ the weight loss was $8,8.3$ and 8.3 


\begin{tabular}{|l|l|l|l|l|l|l|l|l|}
\hline Temperature & ---- & 100 & 200 & 300 & 400 & 500 & 600 & 700 \\
\hline Weight \% & 100 & 97 & 95 & 94 & 92.36 & 92 & 91.7 & 91.7 \\
\hline
\end{tabular}

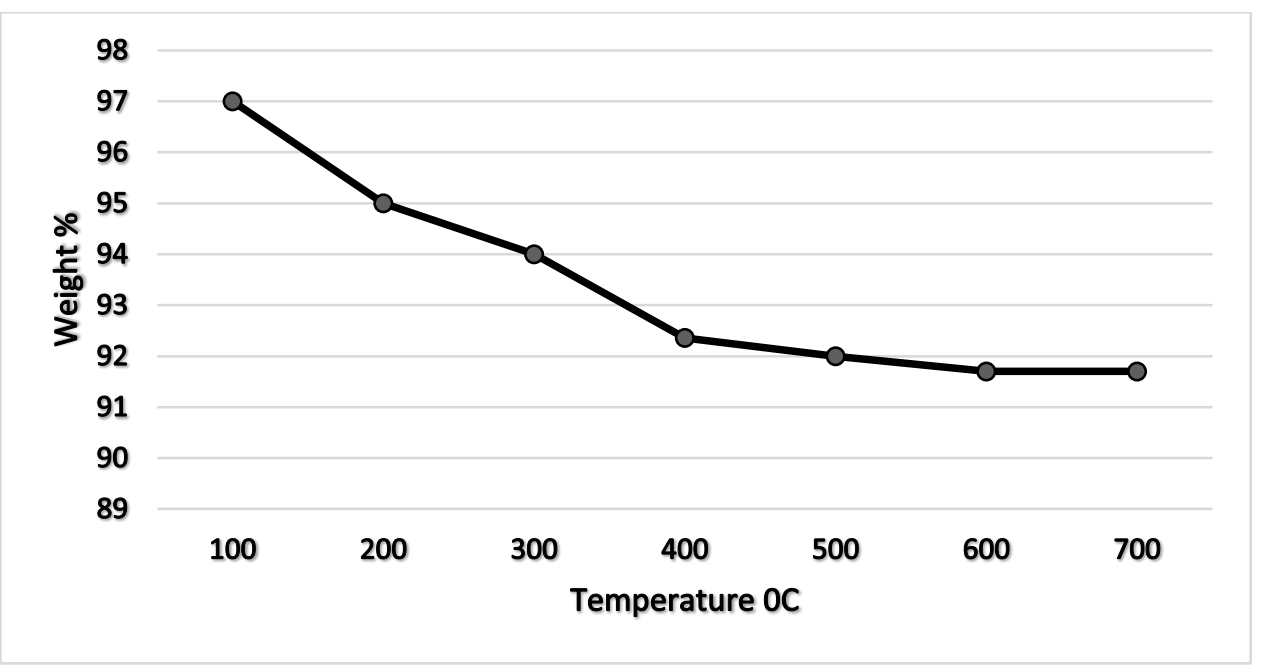

Figure (6): Thermogravimetric analysis of (EMSSM)

\section{Evaluation of the (EMSSM) as adsorbent media:}

\subsection{Adsorbent efficiency of chemically and thermally treated (EMSSM):}

Table (2) show the effect of chemically and thermally treated (EMSSM) on the coagulation performance (expressed as turbidity value NTU).

Table (2): Turbidity removal using chemically and thermally treated (EMSSM).

\begin{tabular}{|c|c|c|c|c|c|c|c|c|}
\hline \multicolumn{9}{|c|}{ Turbidity (NTU) } \\
\hline $\begin{array}{c}\text { Industrial } \\
\text { waste } \\
\text { water }\end{array}$ & \multicolumn{3}{|c|}{$\begin{array}{c}\text { Clarified water by } \\
\text { Thermally treated (EMSSM) }\end{array}$} & \multicolumn{5}{c|}{$\begin{array}{c}\text { Clarified water by } \\
\text { Chemically treated (EMSSM) } \\
\text { using HCl }\end{array}$} \\
\cline { 2 - 8 } & At 400 ${ }^{\circ} \mathrm{C}$ & At $600^{\circ} \mathrm{C}$ & At $800^{\circ} \mathrm{C}$ & $2 \%$ & $4 \%$ & $6 \%$ & $8 \%$ & $10 \%$ \\
\hline \hline 13.00 & 1.70 & 1.20 & 1.20 & 2.80 & 2.00 & 2.18 & 2.70 & 2.90 \\
\hline
\end{tabular}

Flocculation parameters: at: $\mathrm{pH}=8$, coagulant dose $=1 \%$ and settling time $=45 \mathrm{~min}$, at room temperature. 
The data presented in Table (2) showed that the best efficiency (expressed as turbidity removal) for chemically treated (EMSSM) which achieved by $4 \% \mathrm{HCl}$ for 2 hours at room temperature, and for thermally treated at $600{ }^{0} \mathrm{C}$. Thus, they were chosen as best condition for activation of (EMSSM) to complete the flocculation performance.

The untreated and above mentioned thermally and chemically treated (EMSSM) were evaluated as coagulant agents for the treatment of industrial waste water having turbidity valued (13 NTU), Oil and grease $(13.7 \mathrm{mg} / \mathrm{l})$ and organic matter (22 mg/l)and the data obtained by using untreated (EMSSM) is compared with that obtained by using thermally and chemically treated (EMSSM). The best conditions for flocculation were studied in terms of (EMSSM) dosage $، \mathrm{pH}$, settling time and combination of different ferric chloride concentration.

\subsection{Effect of different EMSSM dosage on the coagulation performance:}

The dose evaluation was done for the three EMSSM types (untreated, thermally and chemically treated).Table (3) showed the variation of dosage concentration $(1-8 \%)$ on the adsorption performance of the three studied sorbent agents using the industrial wastewater. The $\mathrm{pH}$ was adjusted at 7.5. It is evident, regardless of the type of sorbent agents and turbidity values that the best flocculation increases by increasing the dosage concentration up to 6 $\%$ after which level off occurs. Overdosing higher than $6 \%$ resulted in the reversal of particle in the liquor solution due to the adsorption of excess (sorbent agents) molecules and it is difficult for the particles to form flocs because of electronic repulsion of the adsorbed agents. 
Turbidity values for (thermally treated EMSSM) were (2.34 NTU) compared to 3.09 for (chemically treated) as well as (5.74 NTU) for (untreated). It is evident that the thermally and chemically treated (EMSSM) gives higher flocculation performance than the other untreated (EMSSM).

Table(3): Effect of adsorbents agents dosage on turbidity removal.

\begin{tabular}{|c|c|c|c|c|c|c|c|c|c|}
\hline \multirow[b]{2}{*}{$\begin{array}{c}\text { (EMSSM) } \\
\text { dosage }(\%)\end{array}$} & \multicolumn{3}{|c|}{ Untreated (EMSSM) } & \multicolumn{3}{|c|}{ Chemically treated (EMSSM) } & \multicolumn{3}{|c|}{ Thermally treated (EMSSMI) } \\
\hline & $\begin{array}{c}\text { Turbidity } \\
\text { (NTU) }\end{array}$ & $\begin{array}{c}\text { Oil } \\
\text { and Grease } \\
(\mathrm{mg} / \mathrm{l})\end{array}$ & $\begin{array}{c}\text { Organic } \\
\text { matter } \\
(\mathrm{mg} / \mathrm{l})\end{array}$ & $\begin{array}{c}\text { Turbidity } \\
\text { (NTU) }\end{array}$ & $\begin{array}{c}\text { Oil } \\
\text { and Grease } \\
(\mathrm{mg} / \mathrm{l})\end{array}$ & $\begin{array}{c}\text { Organic } \\
\text { matter } \\
(\mathrm{mg} / \mathrm{l})\end{array}$ & $\begin{array}{c}\text { Turbidity } \\
\text { (NTU) }\end{array}$ & $\begin{array}{c}\text { Oil } \\
\text { and } \\
\text { Grease } \\
(\mathrm{mg} / \mathrm{l})\end{array}$ & $\begin{array}{c}\text { Organic } \\
\text { matter } \\
(\mathrm{mg} / \mathrm{l})\end{array}$ \\
\hline $\begin{array}{c}\text { Raw Industrial } \\
\text { waste water }\end{array}$ & 16.54 & 13.55 & 27 & 16.54 & 13.55 & 27 & 16.54 & 13.55 & 27 \\
\hline 1 & 12.6 & 10.17 & 14.13 & 10.54 & 8.17 & 12.13 & 9.11 & 7.17 & 10.13 \\
\hline 2 & 10.98 & 9.91 & 14.09 & 8.64 & 7.91 & 12.09 & 7.24 & 6.91 & 10.09 \\
\hline 3 & 8.62 & 9.42 & 13.77 & 7.24 & 7.42 & 11.67 & 5.48 & 6.42 & 9.77 \\
\hline 4 & 5.71 & 9.20 & 13.12 & 4.23 & 7.20 & 11.02 & 3.26 & 6.20 & 9.12 \\
\hline 5 & 4.85 & 8.92 & 12.19 & 4.01 & 6.92 & 10.17 & 3.16 & 5.92 & 9.11 \\
\hline 6 & 5.74 & 8.94 & 12.59 & 3.09 & 7.01 & 10.17 & 1.34 & 5.98 & 9.10 \\
\hline 7 & 6.82 & 9.11 & 12.12 & 4.51 & 7.11 & 10.13 & 1.51 & 6.11 & 9.12 \\
\hline 8 & 6.84 & 9.22 & 12.45 & 5.12 & 7.22 & 10.44 & 2.72 & 6.22 & 9.45 \\
\hline
\end{tabular}

$\mathrm{pH}=8$, settling time $=45 \mathrm{~min}$ at room temperature.

2.3. Effect of different $\mathbf{p H}$ on adsorbent performance: Table (4) show the effect of the $\mathrm{pH}$ of the industrial wastewater on the adsorbent performance (expressed as turbidity value NTU, oil and grease $\mathrm{mg} / \mathrm{l}$ and organic matter $\mathrm{mg} / \mathrm{l}$ ) of untreated, chemically and thermally treated (EMSSM).

The dosage of three examined flocculants was adjusted at $6 \%$. The adsorbs ion performance after $45 \mathrm{~min}$ settling time was measured as a function of the turbidity (NTU), oil and grease and organic matter.

It is well known that the best flocculation occurs when the net charge at the surface of the coagulant and suspended participles is approximately zero. Suspended matter in water with its negative charge will be absorbed at the 
(EMSSM) surface as sorbent agent and best adsorption with highly magnitude of negatively charged suspended particles removal was obtained at $\mathrm{pH} 7.5$ - 9.5 for the three examined coagulant substances (untreated, chemically and thermally treated EMSSM). The adsorption performance for thermally treated and chemically treated (EMSSM) is better than for untreated (EMSSM).

Table (4): Effect of $\mathrm{pH}$ on the turbidity, oil and grease and organic matter removal.

\begin{tabular}{|c|c|c|c|c|c|c|c|c|c||}
\hline \multirow{2}{*}{$\mathrm{pH}$} & \multicolumn{3}{|c|}{ Untreated (EMSM) } & \multicolumn{3}{c|}{ Chemically treated (EMSSM) } & \multicolumn{3}{c|}{ Thermally treated (EMSSM) } \\
\cline { 2 - 13 } & $\begin{array}{c}\text { Turbidity } \\
(\mathrm{NTU})\end{array}$ & $\begin{array}{c}\text { Oil and } \\
\text { Grease } \\
(\mathrm{mg} / \mathrm{l})\end{array}$ & $\begin{array}{c}\text { Organic } \\
\text { matter } \\
(\mathrm{mg} / \mathrm{l})\end{array}$ & Turbidity & $\begin{array}{c}\text { Oil and } \\
\text { Grease } \\
(\mathrm{mg} / \mathrm{l})\end{array}$ & $\begin{array}{c}\text { Organic } \\
\text { matter } \\
(\mathrm{mg} / \mathrm{l})\end{array}$ & $\begin{array}{c}\text { Turbidity } \\
(\mathrm{NTU})\end{array}$ & $\begin{array}{c}\text { Oil and } \\
\text { Grease } \\
(\mathrm{mg} / \mathrm{l})\end{array}$ & $\begin{array}{c}\text { Organic } \\
\text { matter } \\
(\mathrm{mg} / \mathrm{l})\end{array}$ \\
\hline $\begin{array}{c}\text { Raw } \\
\text { Industrial } \\
\text { waste water }\end{array}$ & 16.54 & 13.55 & 27 & 16.54 & 13.55 & 27 & 16.54 & 13.55 & 27 \\
\hline \hline 6 & 6.54 & 10.17 & 13.13 & 2.40 & 4.17 & 7.13 & 2.10 & 6.17 & 9.13 \\
\hline 6.5 & 6.11 & 9.91 & 13.09 & 2.20 & 3.91 & 7.09 & 2.01 & 5.91 & 9.09 \\
\hline 7 & 5.90 & 9.42 & 12.77 & 2.08 & 3.42 & 6.67 & 1.90 & 5.42 & 8.77 \\
\hline 7.5 & 5.79 & 8.98 & 12.62 & 2.00 & 3.20 & 6.02 & 1.70 & 5.20 & 8.12 \\
\hline 8 & 5.74 & 8.94 & 12.59 & 3.09 & 7.01 & 10.17 & 1.34 & 5.98 & 9.10 \\
\hline 8.5 & 5.30 & 8.94 & 12.59 & 2.10 & 3.01 & 5.17 & 1.40 & 4.98 & 7.39 \\
\hline 9 & 5.08 & 8.71 & 12.12 & 2.50 & 3.11 & 5.13 & 1.40 & 5.11 & 7.12 \\
\hline 9.5 & 5.10 & 8.72 & 12.45 & 2.70 & 3.22 & 5.44 & 1.90 & 5.22 & 7.45 \\
\hline 10 & 5.50 & 9.12 & 13.66 & 3.40 & 3.32 & 5.56 & 2.60 & 5.32 & 7.66 \\
\hline 10.5 & 5.78 & 9.25 & 13.89 & 3.60 & 3.35 & 5.79 & 2.80 & 5.35 & 7.89 \\
\hline
\end{tabular}

2.4. Effect of different contact time: Table (5) represent the effect of the contact time on the adsorption performance expressed as turbidity value (NTU), oil and grease $(\mathrm{mg} / \mathrm{l})$ and organic matter $(\mathrm{mg} / \mathrm{l})$, using untreated, thermally and chemically treated (EMSSM).The dosage concentrations and $\mathrm{pH}$ were adjusted as previous optimum conditions. It can be seen that by increasing the settling time from 5- 60 min the turbidity, organic matter and 
oil and grease values of were decreased. The more suspended fine particles in water need more time for sedimentation in a colloidal particle. A particle of diameter $0.1 \mathrm{~mm}$ needs $38 \mathrm{sec}$ for sedimentation. Meanwhile, a particles of diameter $1 \times 10^{-5} \mathrm{~mm}$ need 6.3 year for sedimentation (Faust and Aly 1998). The turbidity (NTU), oil and grease $(\mathrm{mg} / \mathrm{l})$ and organic matter $(\mathrm{mg} / \mathrm{l})$ values when using untreated (EMSSM) agent is less than that of the values obtained by thermally and chemically treated (EMSSM. However, for the removal \% of turbidity, oil and grease and organic matter using thermally treated (EMSSM) is greater than chemically treated mean that thermally treated (EMSSM) have the more effective action for adsorption performance.

Table (5): Effect of Settling time on the turbidity,oil and grease and organic matter removal in water.

\begin{tabular}{|c|c|c|c|c|c|c|c|c|c|}
\hline \multirow[b]{2}{*}{$\begin{array}{l}\text { Time } \\
(\min )\end{array}$} & \multicolumn{3}{|c|}{ Untreated (EMSSM) } & \multicolumn{3}{|c|}{$\begin{array}{l}\text { Chemically treated } \\
\text { (EMSSM) }\end{array}$} & \multicolumn{3}{|c|}{$\begin{array}{l}\text { Thermally treated } \\
\text { (EMSSM) }\end{array}$} \\
\hline & $\begin{array}{c}\text { Turbid } \\
\text { ity } \\
\text { (NTU) } \\
\end{array}$ & $\begin{array}{l}\text { Oil and } \\
\text { Grease } \\
(\mathrm{mg} / \mathrm{l})\end{array}$ & $\begin{array}{c}\text { Organic } \\
\text { matter } \\
(\mathrm{mg} / \mathrm{l})\end{array}$ & $\begin{array}{c}\text { Turbidit } \\
\text { y } \\
\text { (NTU) }\end{array}$ & $\begin{array}{c}\text { Oil and } \\
\text { Grease } \\
(\mathrm{mg} / \mathrm{l})\end{array}$ & $\begin{array}{c}\text { Organic } \\
\text { matter } \\
(\mathrm{mg} / \mathrm{l})\end{array}$ & $\begin{array}{c}\text { Turbidity } \\
\text { (NTU) }\end{array}$ & $\begin{array}{l}\text { Oil and } \\
\text { Grease } \\
(\mathrm{mg} / \mathrm{l})\end{array}$ & $\begin{array}{c}\text { Organic } \\
\text { matter } \\
(\mathrm{mg} / \mathrm{l}) \\
\end{array}$ \\
\hline $\begin{array}{c}\text { Raw } \\
\text { Industrial } \\
\text { waste } \\
\text { water }\end{array}$ & 16.54 & 13.55 & 27 & 16.54 & 13.55 & 27 & 16.54 & 13.55 & 27 \\
\hline$\overline{5}$ & 7.74 & 11.97 & 14.13 & 4.45 & 8.17 & 12.14 & 2.80 & 7.17 & 11.13 \\
\hline 10 & 6.77 & 10.31 & 13.99 & 4.21 & 7.91 & 11.99 & 2.01 & 6.99 & 10.09 \\
\hline 15 & 6.10 & 9.92 & 13.37 & 3.99 & 7.42 & 11.67 & 1.90 & 6.72 & 10.07 \\
\hline 20 & 5.99 & 9.48 & 13.22 & 3.90 & 7.20 & 11.02 & 1.80 & 6.60 & 9.92 \\
\hline 30 & 5.94 & 9.14 & 12.99 & 3.59 & 7.41 & 10.77 & 1.44 & 6.28 & 9.50 \\
\hline 45 & 5.74 & 8.94 & 12.59 & 3.09 & 7.01 & 10.17 & 1.34 & 5.98 & 9.10 \\
\hline 60 & 5.74 & 8.94 & 12.59 & 3.09 & 7.01 & 10.17 & 1.34 & 5.98 & 9.10 \\
\hline
\end{tabular}

$($ EMSSM) dosage for untreated, chemically and thermally treated $=6 \%$ and $\mathrm{pH} 8$ at room temperature. 


\section{Effect of combination between ferric chloride as conventional coagulant and (EMSSM):}

The data obtained in Table (6) show the effect of different ferric chloride doses (20 to 40ppm) / untreated and treated (EMSSM) concentrations on the turbidity values of industrial wastewater. The flocculation and adsorption action were performed at optimum conditions of 45 min settling time and $\mathrm{pH}$ 8 at room temperature. The results clarify the following aspects:

Increasing (EMSSM) concentrations of the three examined sorbent agents were accompanied by observed increment of the flocculation performance of the treated industrial waste water up to $4 \%$. A point of interest is that ferric chloride used in best water flocculation with a concentration of $35-40 \mathrm{ppm}$ which give turbidity value $2.74(\mathrm{NTU})$. Also, from our previous data best flocculation for our studied compounds was $6 \mathrm{ppm}$. Combination between ferric chloride and the studied three sorbent agents is associated by pronounced decrease of its concentration to $25 \mathrm{ppm}$ for ferric chloride and $4 \%$ for the studied three sorbent agents. Moreover, the quality of clarification is more improved than that obtained for each component alone. For intense, the turbidity value (NTU) for 4\% dosage, chemically treated (EMSSM), thermally treated and untreated (EMSSM) 4.23, 3.26 and 5.74 (NTU) respectively Table (3) against turbidity value of 1.23, 1.11and 2.42 (NTU) for $4 \%$ chemically, thermally and untreated (EMSSM) respectively with $25 \mathrm{ppm}$ ferric chloride Tables (6-8). Nevertheless the data obtained from Tables $(7,8)$ shows that at constant ferric chloride concentration $(25 \mathrm{ppm})$ the variation of flocculation performance as turbidity function follow the following sequence: 
Thermally treated $(\mathrm{EMSSM})+25 \mathrm{ppm}$ ferric chloride > chemically treated $(\mathrm{EMSSM})+25 \mathrm{ppm}$ ferric chloride > untreated $(\mathrm{EMSSM})+25 \mathrm{ppm}$ ferric chloride $>25$ ppm ferric chloride.

Table (6): Effect of combination between ferric chloride and chemically treated (EMSSM)at different dosage on the turbidity removal.

\begin{tabular}{|c|c|c|c|c|c|}
\hline \multirow{2}{*}{$\begin{array}{c}\text { Chemically } \\
\text { treated(EMSSM) } \\
\text { dosage \% }\end{array}$} & \multicolumn{5}{|c|}{ Ferric chloride concentration } \\
\cline { 2 - 6 } & $\mathbf{2 0} \mathbf{~ p p m}$ & $\mathbf{2 5} \mathbf{~ p p m}$ & $\mathbf{3 0} \mathbf{~ p p m}$ & $\mathbf{3 5} \mathbf{~ p m}$ & $\mathbf{4 0} \mathbf{~ p p m}$ \\
\hline \hline 0 & 2.92 & 2.87 & 2.70 & 2.74 & 2.76 \\
\hline 2 & 1.54 & 1.42 & 1.46 & 1.49 & 1.52 \\
\hline 4 & 1.37 & 1.23 & 1.26 & 1.28 & 1.32 \\
\hline 6 & 1.99 & 1.14 & 1.21 & 1.23 & 1.25 \\
\hline 8 & 1.45 & 1.24 & 1.27 & 1.29 & 1.30 \\
\hline
\end{tabular}

Industrial wastewater sample of (13 NTU), $\mathrm{pH} 8$ and settling time 45 min.

Table (7): Effect of combination between ferric chloride and thermally treated (EMSSM) at different dosage on the turbidity removal.

\begin{tabular}{|c|c|c|c|c|c|}
\hline \multirow{2}{*}{$\begin{array}{c}\text { thermally treated } \\
\text { (EMSSM) }\end{array}$} & \multicolumn{5}{|c|}{ Turbidity (NTU) } \\
\cline { 2 - 6 } dosage \% & \multicolumn{5}{|c|}{ Ferric chloride concentration } \\
\cline { 2 - 6 } & $\mathbf{2 0} \mathbf{~ p p m}$ & $\mathbf{2 5} \mathbf{~ p p m}$ & $\mathbf{3 0} \mathbf{~ p p m}$ & $\mathbf{3 5} \mathbf{~ p p m}$ & $\mathbf{4 0} \mathbf{~ p m}$ \\
\hline \hline 0 & 2.92 & 2.87 & 2.70 & 2.74 & 2.76 \\
\hline 2 & 1.49 & 1.40 & 1.43 & 1.45 & 1.47 \\
\hline 4 & 1.35 & 1.11 & 1.24 & 1.26 & 1.29 \\
\hline 6 & 1.25 & 1.15 & 1.19 & 1.21 & 1.23 \\
\hline 8 & 1.37 & 1.21 & 1.24 & 1.26 & 1.28 \\
\hline
\end{tabular}

Industrial wastewater sample of (13 NTU), $\mathrm{pH} 8$ and settling time $45 \mathrm{~min}$ 
Table (8): Effect of combination between ferric chloride and untreated (EMSSM) at different dosage on the turbidity removal.

\begin{tabular}{|c|c|c|c|c|c|}
\hline \multirow{3}{*}{$\begin{array}{l}\text { Untreated } \\
\text { (EMSSM) } \\
\text { dosage \% }\end{array}$} & \multicolumn{5}{|c|}{ Turbidity (NTU) } \\
\hline & \multicolumn{5}{|c|}{ Ferric chloride concentration } \\
\hline & 20 ppm & 25 ppm & 30 ppm & 35 ppm & 40 ppm \\
\hline 0 & 2.92 & 2.87 & 2.70 & 2.74 & 2.76 \\
\hline 2 & 2.72 & 2.57 & 2.60 & 2.62 & 2.64 \\
\hline 4 & 2.63 & 2.42 & 2.46 & 2.50 & 2.54 \\
\hline 6 & 2.54 & 2.38 & 2.41 & 2.46 & 2.50 \\
\hline 8 & 2.59 & 2.51 & 2.54 & 2.56 & 2.58 \\
\hline
\end{tabular}

Industrial wastewater sample of (13 NTU), $\mathrm{pH} 8$ and settling time 45 min.

3.1. Characteristic of treated water: To explain clearly the importance of this study a collective table was made to compare the characteristic of industrial wastewater taken as a control, with that after independently treated with 25 ppm of ferric chloride and $4 \%$ of three studied different (EMSSM).

It can be seen that the conductivity upon use of ferric chloride caused an increasing of its value $(1357 \mu \mathrm{S})$ than that of the industrial wastewater $(1375 \mu \mathrm{S})$ while, treated and untreated (EMSSM) showed a slight increase when a mixture of both of them and ferric chloride was used.

The turbidity of the treated water was considerably decreased by using mixture of ferric chloride and treated (EMSSM) and reached to lowest turbidity values of 1.5 NTU against a value of (2.3) NTU obtained using combination of ferric chloride with untreated (EMSSM). The total alkalinity was affected by treatment with ferric chloride, (EMSSM) or their admixture and the recorded values were 109, 118, 111, 122, 114, 121 and110 respectively, while that of industrial waste water was 167. 
With respect to the total hardness it was affected with the treatment by, treated and untreated (EMSSM) or their mixture with ferric chloride.

The results in Table (9) assured the fact that using ferric chloride (40 $\mathrm{ppm})$ or treated and untreated (EMSSM) $(6 \mathrm{ppm})$ caused a significant reduction of organic matter expressed as $\mathrm{KMnO}_{4}$ and oil and grease $\mathrm{mg} / \mathrm{l}$ of the treated water. 
Table (9): Variation of water constituents at the optimum dosage of ferric chloride and different prepared flocculants agent's concentration and combination of them

\begin{tabular}{|c|c|c|c|c|c|c|c|c|c|c|c|c|c|c|}
\hline 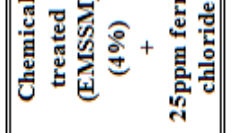 & 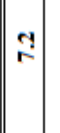 & $\stackrel{\mathbb{E}}{\mathrm{E}}$ & a & 0 & $\stackrel{̊}{\Xi}$ & 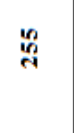 & $\stackrel{9}{\underset{7}{1}}$ & $\stackrel{m}{9}$ & $\stackrel{亏}{ت}$ & 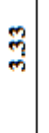 & $\begin{array}{l}\frac{100}{40} \\
\end{array}$ & $\begin{array}{l}\vec{\infty} \\
\vec{j}\end{array}$ & $\begin{array}{l}\overrightarrow{0} \\
\dot{\leftrightarrow} \\
\dot{v}\end{array}$ & $\begin{array}{l}\overrightarrow{0} \\
\dot{\hat{v}}\end{array}$ \\
\hline 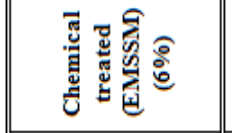 & $\stackrel{\infty}{\infty}$ & 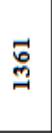 & aี & 0 & తี & :̊ํㅁ & త్ & $\begin{array}{l}9 \\
\stackrel{9}{9} \\
\stackrel{9}{9}\end{array}$ & $\stackrel{9}{\exists}$ & ন্ & $\begin{aligned} \overrightarrow{0} \\
\vec{j}\end{aligned}$ & $\stackrel{m}{\circ}$ & $\begin{array}{l}\overrightarrow{0} \\
\dot{\vec{v}}\end{array}$ & $\begin{array}{l}\overrightarrow{0} \\
\dot{\hat{v}}\end{array}$ \\
\hline 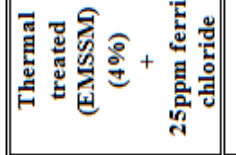 & 2 & $\underset{d}{\mathbb{N}}$ & 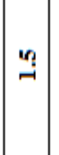 & 0 & $\vec{\Xi}$ & 吕 & త్) & 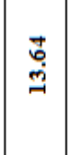 & $\stackrel{\Im}{\exists}$ & $\overrightarrow{\mathrm{i}}$ & $\stackrel{7}{7}$ & $\begin{array}{l}\mathbb{N} \\
\vec{j}\end{array}$ & $\begin{array}{l}\overrightarrow{0} \\
\dot{\vec{v}}\end{array}$ & $\begin{array}{l}\vec{\partial} \\
\dot{\nabla}\end{array}$ \\
\hline 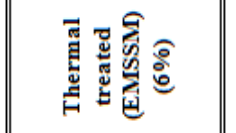 & $\stackrel{\infty}{\infty}$ & 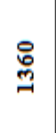 & 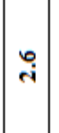 & 0 & สี & : & $\overrightarrow{\mathrm{m}}$ & $\begin{array}{l}\text { 总 } \\
\stackrel{్}{3}\end{array}$ & 3 & $\underset{m}{7}$ & ఫี & $\overrightarrow{\overrightarrow{7}}$ & $\begin{array}{l}\overrightarrow{\dot{O}} \\
\dot{\hat{\theta}}\end{array}$ & $\begin{array}{l}\overrightarrow{0} \\
\dot{\nabla}\end{array}$ \\
\hline 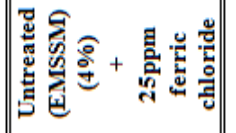 & $n$ & 点 & 3 & 0 & $\Xi$ & 过 & $\stackrel{?}{\underset{7}{1}}$ & \begin{tabular}{l}
$\mathbf{T}$ \\
\multirow{2}{*}{}
\end{tabular} & $\stackrel{x_{0}}{\exists}$ & ๙્. & $\begin{array}{l}\stackrel{8}{0} \\
\stackrel{+}{+}\end{array}$ & $\stackrel{?}{+}$ & $\begin{array}{l}\overrightarrow{0} \\
\dot{\vec{v}}\end{array}$ & $\begin{array}{l}\vec{\Xi} \\
\dot{\hat{v}}\end{array}$ \\
\hline 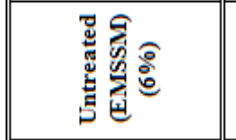 & $\stackrel{\infty}{\sim}$ & $\begin{array}{l}: 0 \\
: 0 \\
\end{array}$ & $\mid \begin{array}{c}\infty \\
\dot{\infty}\end{array}$ & 0 & $\stackrel{\infty}{\exists}$ & $\sqrt{8}$ & త్) & 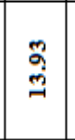 & ] & $\vec{m}$ & $\begin{array}{l}\vec{\Phi} \\
+\end{array}$ & $\stackrel{m}{+}$ & $\begin{array}{l}\overrightarrow{0} \\
\dot{\dot{v}}\end{array}$ & $\begin{array}{l}\text { ठे. } \\
\dot{\nabla}\end{array}$ \\
\hline 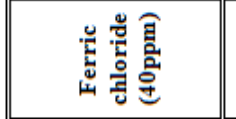 & $\left|\begin{array}{l|l}\infty \\
\vdots \\
0\end{array}\right|$ & $\stackrel{n}{n}$ & बे| & 0 & ఏ & $\begin{array}{l}\infty \\
\text { : } \\
\text { D }\end{array}$ & ले & $\begin{array}{l}\overrightarrow{0} \\
\dot{ \pm} \\
\overrightarrow{ \pm}\end{array}$ & 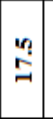 & 9 & $\begin{array}{l}\mathbb{7} \\
0 \\
0\end{array}$ & बું & 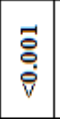 & ¿̊. \\
\hline 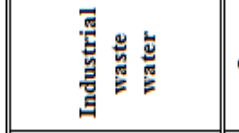 & $\infty$ & $\stackrel{0}{\stackrel{0}{9}}$ & 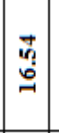 & 0 & 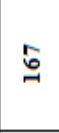 & 占 & 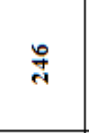 & $\vec{A}$ & $\pi$ & 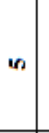 & 点 & 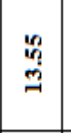 & $\mid \begin{array}{l}\overrightarrow{0} \\
\dot{\partial} \\
\dot{0}\end{array}$ & ¿̊ \\
\hline 这 & 圆 & 跑 & $\mid$ & 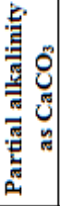 & 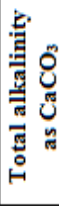 & 曾 & 焉 & 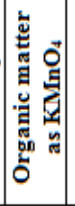 & 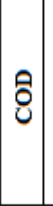 & రి & 具 & 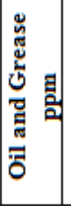 & 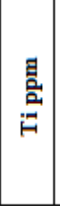 & \\
\hline
\end{tabular}




\section{REFERENCES}

Abdelaal, A.M., (2004): Using a natural coagulant for treating wastewater. Eighth International Water Technology Conference, IWTC8, Alexandria, Egypt.

Abdellal, A. M.; El-Salmawy, M.S. and Abdelrahman, A. A, (2003): Using a small dosage of coagulants to improve the efficiency of Flocculation process, the fifth Egyptian Syrian conference in chemical and petroleum engineering, Faculty of petroleum and Mining engineering, Suez, Egypt, I., 300-312, October 13-16

APHA, 2012. "American Public Health Association", standard methods for the examination of water and wastewater $\left(19^{\text {th }}\right.$ edition $)$

Babel, S. and Kurniawan, T.A.,( 2003): Low-cost adsorbents for heavy metals uptake from contaminated water: a review. Journal of Hazardous Materials, B97, 97, Issue (1-3), 219-243

Bekkum , H. Van.; Flanigen , E.M. ; Jacobs , P.A. and J.C. Jensen , (2001): Zeolites and molecular sieves. An historical perspective, in Introduction to Zeolite Science and Practice, 2nd edn, Stud. Surf. Sci. Catal. , 137, Elsevier, Amsterdam, pp. $11-35$.

Betancourt, D, Díaz, Y and Martirena, F., (2013): "Influence of the addition of $2 \%$ calcium carbonate during the manufacturing process of red ceramic brick: drying and firing stage", Revista Ingeniería de Construcción RIC. 28 (2), 113-124

Dilek, F.B. and Bese, S., (2001): Treatment of pulping effluents by using alum\& clay-color removal and sludge characteristics. Water SA. 27 (3), 3- 366

Faust, S.D. and Aly, O.M. , (1998): In "chemistry of water treatment", 2nd edition, Lewis Publication, Boca Raton, London, chapter.6, pp. $369-466$

Juang, R.S.; W.U.F.C. and Tseng, R.L. ,(1997): The ability of activated clay for the adsorption of dyes from aqueous solutions. Environ .Technol. 18 525-531

Kendall, T., (1996): “Industrial Minerals Information”, Ltd., London, pp 7378 
Konig, T.N.; Shulami.S. and Rytwo, G., (2012): "Brine wastewater pretreatment using clay minerals and organ clays as flocculants". Applied clay science -Elsevier, 67-68 , 119-124

Mittal, A.k. and Mehrotra, L., (1981): Decolorisation of pulp and paper mill waste using alum and clay, Indian J. Environ. Health, 23 (3), 203214

Samiey, B., Cheng, C., \& Wu, J. (2014): Organic-inorganic hybrid polymers as adsorbents for removal of heavy metal ions from solutions: A review. Materials, 7, 673-726.

Stephenson, R.J. and Duff, J.B., (1996): "Coagulation\& precipitation of a mechanical pulping effluent-II toxicity removal and metal salt recovery". Water Research Journal, 30, 793-798

Wang, S. and Peng, Y., (2010): "Natural zeolites as effective adsorbents in water and wastewater treatment". Chemical Engineering Journal $156,11-24$

Zhao, G.; Zhang, H.; Fan, Q.; Ren, X.; Li, J.; Chen, Y.; Wang, X., (2010): Sorption of copper(II) onto super-adsorbent of bentonitepolyacrylamide composites. J. Hazard. Mater, 173, 661-668. 


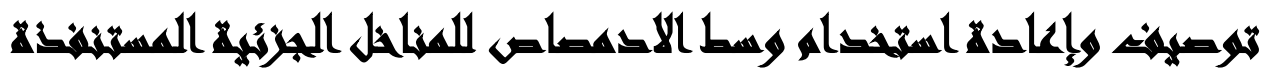

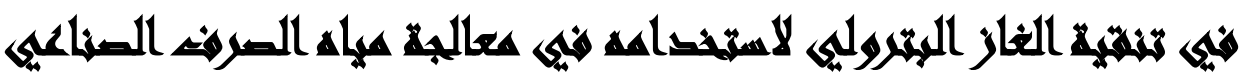

[r]

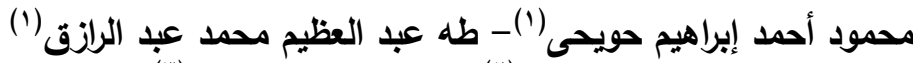

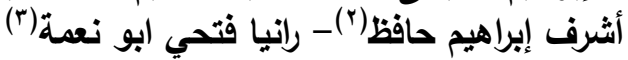

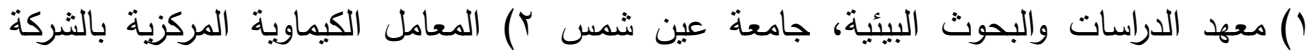

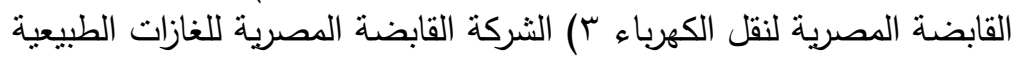

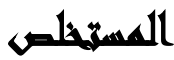

يعتبر وسط الادمصاص للمناخل الجزئية المستتفذة في تتقية الغازات البترولية كمادة مخلفات

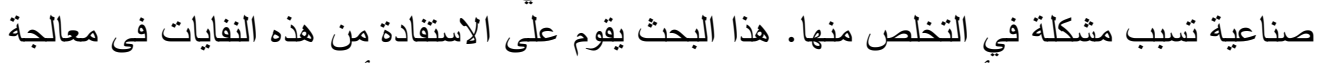

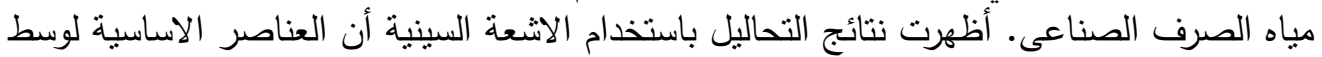

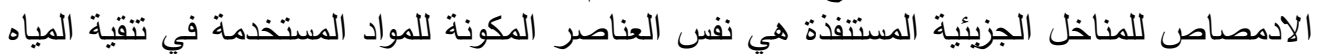

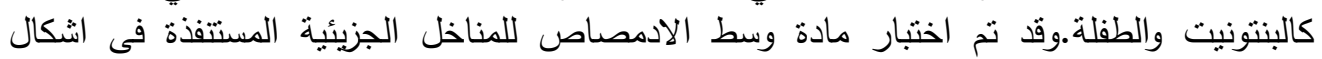

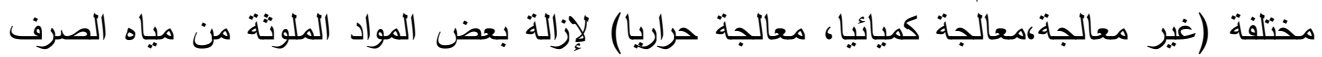

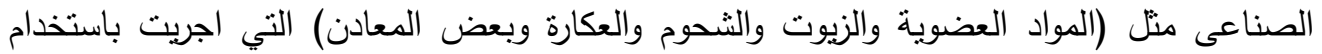

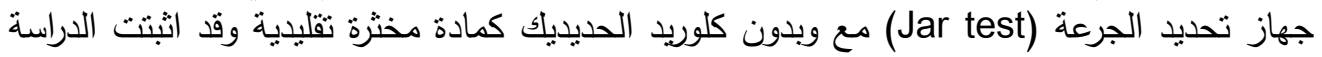

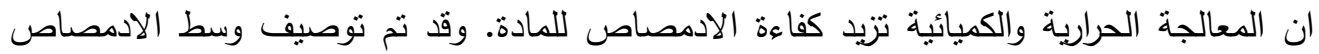

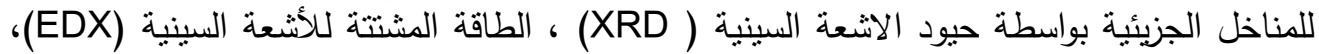

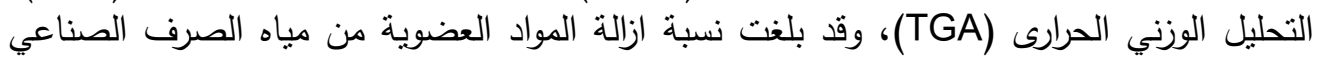

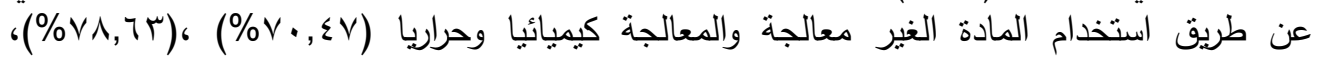

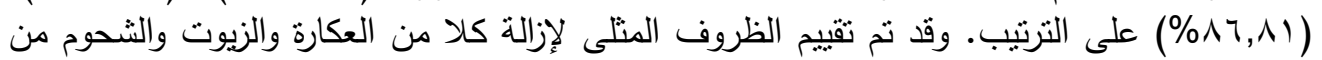
مباه الصرف الصناعي حيث ان العوامل المؤثرة هي الجرعة- الوقت- الاس الهيدروجينى -درجة

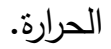
الكلمات المفتاحية: مناخل جزيئية، مواد الادمصاص، معالجة المياه، الطفلة 